\title{
Evaluation of Hot Pepper (Capsicum annuum L.) Genotypes for Heat Tolerance during Reproductive Phase
}

\author{
Navjyot Kaur ${ }^{1 * \#}$, M. S Dhaliwal ${ }^{2}$, Salesh Jindal ${ }^{2}$ and Parjeet Singh ${ }^{2}$ \\ ${ }^{1}$ Dept. of Botany, ${ }^{2}$ Dept. of Vegetable Science, Punjab Agricultural University, Ludhiana, Punjab (141 004), India \\ ${ }^{\sharp}$ Presently Dept. of Agronomy, Punjab Agricultural University, Ludhiana, Punjab (141 004), India
}

\section{Article History}

Manuscript No. AR1386

Received in $31^{\text {st }}$ May, 2015

Received in revised form $28^{\text {th }}$ January, 2016

Accepted in final form $4^{\text {th }}$ February, 2016

\section{Correspondence to}

${ }^{*}$ E-mail: navjyot_grewal@yahoo.com

\section{Keywords}

Chilli, heat stress, heat susceptibility index, fruit set

\begin{abstract}
Eleven hot pepper genotypes (viz., Sel-11, PLS-1, Sel-Dev, DCL-524, Punjab Surkh, VR-16, Pepsi-17-2, MS-12, S-217621, PBC-535 and Faslima) were evaluated for heat tolerance during summer 2011 to identify the most appropriate genotypes under agro-climatic conditions of Punjab. High temperature $\left(40 / 24^{\circ} \mathrm{C}\right.$, day/night) decreased fruit set in all the test genotypes with overall mean of $18.2 \%$ against $65.0 \%$ fruit set at optimum temperature $\left(34 / 16{ }^{\circ} \mathrm{C}\right.$, day/night). High temperature also caused significant reduction in pollen viability, seed number fruit ${ }^{-1}$, fruit length and fruit diameter. Heat susceptibility index (HSI) was used to measure heat stress tolerance of hot pepper germplasm for identifying genotypes exhibiting least reduction in fruit set percentage, pollen viability, seed number fruit ${ }^{-1}$, fruit length and fruit diameter due to high temperature. On the basis of HSI for fruit set, only one genotype Pepsi-17-2 was classified as highly heat tolerant $(\mathrm{HSI}<0.5)$. Four genotypes namely DCL- 524, VR-16, MS-12 and S-217621 were classified as moderately heat tolerant, showing HSI between 0.5 and 1.0. These five genotypes viz., Pepsi-17-2, DCL524, VR-16, MS-12 and S-217621 are most promising to initiate hybrid breeding program for the development of heat tolerant cultivars of chilli as maintenance of fruit set under high temperature is the most desirable character.
\end{abstract}

\section{Introduction}

Pepper (Capsicum annuum L.) is an important vegetable crop grown in India, both for fresh market and processing industry. Hot pepper requires comparatively a longer growing season of 130-150 days and fruit setting is drastically reduced if dry weather is accompanied by high temperature (Erickson and Markhart, 2002). High temperature stress is one of the major limiting factors for pepper production. The optimum day temperature for growth and productivity of pepper plants has been found to be $20-30{ }^{\circ} \mathrm{C}$ and yields are significantly decreased when temperature rises above $30{ }^{\circ} \mathrm{C}$ (Berke et al., 2005). High temperature affects several physiological and biochemical processes of the plant leading to impaired growth and reproduction; shorten life cycle by hastening flowering and maturity, reduced yield and production of poor quality fruits (Long and Ort, 2010). High temperature induced decrease in crop yield has been closely linked to damaged thylakoid membranes, decreased chlorophyll content and increased membrane leakage (Prasad et al., 2008; Ristic et al., 2007). Cell membrane thermostability has been found to be a useful physiological parameter for selection of heat tolerant genotypes in C. annuum and C. fructescence (Usman et al., 2014). Another common-method of selecting plants for abiotic stress tolerance is to identify selection criteria during early stages of plant development, which may be correlated with tolerance during reproductive stages. Unfortunately, heat stress tolerance is a developmentally regulated, stage specific phenomenon and tolerance at one stage of plant development may not be correlated with tolerance at other developmental stages (Wahid et al., 2007). Thus, present study was undertaken to evaluate hot pepper germplasm for high temperature stress tolerance during reproductive phase to identify heat tolerant genotypes that can be utilized in hybrid breeding programmes.

\section{Materials and Methods}

A field evaluation of eleven hot pepper genotypes viz., Sel-11, PLS-1, Sel-Dev, DCL-524, Punjab Surkh, VR-16, Pepsi-17-2, MS-12, S-217621, PBC-535 and Faslima was conducted for heat tolerance, keeping Royal Wonder genotype of sweet pepper as a sensitive check. The experiment was conducted 
at the Research Farm of the Department of Vegetable Science, Punjab Agricultural University, Ludhiana in a randomized complete block design with three replications during summer 2011. The recommended package of practices was followed to raise the crop (Anonymous, 2011). Data were recorded from ten randomly selected representative plants. Fruit set $(\%)$, pollen viability, seed set, fruit length $(\mathrm{cm})$ and fruit diameter (mm) were recorded from April to August (data not presented). Maximum and minimum fruit set percentage of all the test genotypes was observed during first week of April (optimum temperature regime- $34 / 16^{\circ} \mathrm{C}$ day/night) and second week of June (high temperature regime $-40 / 24{ }^{\circ} \mathrm{C}$ day/ night), respectively. Fruit set percentage of each genotype was assessed by tagging twenty flowers and it was computed by using the following formula:

$$
\text { Fruit set } \%=\frac{\text { Number of set fruits }}{\text { total no. of flowers tagged }} \times 100
$$

Pollen viability was observed by staining pollen grains with $2 \%$ acetocarmine stain. Viable pollen grains stained pink to bold red and non-viable pollen appeared colorless under the microscope. The percentage of pollen viability was calculated by using the following formula:

Pollen viability $\%=\frac{\text { Number of viable pollen grains }}{\text { total number of pollen grains }} \times 100$ Fruits were carefully dissected to calculate seed number fruit ${ }^{-1}$. Fruit length and diameter were recorded from the randomly selected green mature fruits using centimeter scale and vernier caliper, respectively.

Heat susceptibility indices were calculated for fruit set, pollen viability, seed number fruit $^{-1}$, fruit length and diameter as described by Fischer and Maurer (1978). Heat susceptibility index for fruit set percentage was calculated by using the following formula:

$$
\mathrm{HSI}=(1-\mathrm{Y} / \mathrm{Yp}) \mathrm{D}^{-1}
$$

Where, $\mathrm{Y}=$ percentage fruit set of a genotype at high temperature $\left(40 / 24{ }^{\circ} \mathrm{C}\right.$, day/night), $\mathrm{Yp}=$ percentage fruit set of same genotype at optimum temperature $\left(34 / 16^{\circ} \mathrm{C}\right.$, day/night $)$ $\mathrm{D}$ ( stress intensity $)=(1-\mathrm{X} / \mathrm{Xp})$

Where, $\mathrm{X}=$ mean $\mathrm{Y}$ of all genotypes and $\mathrm{Xp}=$ mean $\mathrm{Yp}$ of all genotypes. Similarly HSI for other parameters was calculated. Critical difference values were calculated by doing analysis of variance (ANOVA) as described by Singh et al., 1991).

\section{Results and Discussion}

At optimum temperature (OT) regime of $34 / 16^{\circ} \mathrm{C}$ (day/night), fruit set percent among hot pepper genotypes varied from 26 to $86 \%$ with overall mean of $65.0 \%$ as compared to $23.3 \%$ fruit set in Royal Wonder (Table 1). Maximum fruit set percentage at OT was observed for the genotype S-217621 and it was statistically at par with genotypes DCL-524, PLS-1 and VR-16. High temperature (HT) regime $\left(40 / 24^{\circ} \mathrm{C}\right.$, day/night) decreased
Table 1: Effect of temperature on fruit set and pollen viability of different hot pepper genotypes. (OT-34/16 ${ }^{\circ} \mathrm{C}$ day/night,

\begin{tabular}{|c|c|c|c|c|c|c|}
\hline \multirow[t]{2}{*}{ Genotype } & \multicolumn{3}{|c|}{ Fruit set (\%) } & \multicolumn{2}{|c|}{$\begin{array}{c}\text { Pollen vi- } \\
\text { ability (\%) }\end{array}$} & \multirow[b]{2}{*}{ HSI } \\
\hline & OT & HT & HSI & OT & HT & \\
\hline Sel-11 & 72.6 & 18.9 & 1.03 & 80 & 80 & 0 \\
\hline PLS-1 & 81.9 & 12.0 & 1.18 & 100 & 80 & 1.11 \\
\hline Sel. Dev & 51.9 & 7.8 & 1.18 & 100 & 80 & 1.11 \\
\hline DCL-524 & 83.1 & 25.2 & 0.97 & 90 & 80 & 0.61 \\
\hline $\begin{array}{l}\text { Punjab } \\
\text { Surkh }\end{array}$ & 67.6 & 4.7 & 1.29 & 80 & 60 & 1.39 \\
\hline VR-16 & 80.0 & 24.4 & 0.96 & 80 & 70 & 0.67 \\
\hline $\begin{array}{l}\text { Pep- } \\
\text { si-17-2 }\end{array}$ & 53.3 & 46.0 & 0.18 & 80 & 80 & 0 \\
\hline PBC-535 & 34.4 & 0 & 1.39 & 90 & 70 & 1.22 \\
\hline MS-12 & 77.9 & 25.0 & 0.94 & 90 & 85 & 0.33 \\
\hline S-217621 & 86.0 & 36.4 & 0.8 & 90 & 80 & 0.61 \\
\hline Faslima & 26.0 & 0 & 1.39 & 80 & 70 & 0.67 \\
\hline $\begin{array}{l}\text { Royal } \\
\text { Wonder }\end{array}$ & 23.3 & 4.8 & 1.10 & 100 & 30 & 3.89 \\
\hline $\mathrm{SEm} \pm$ & 6.7 & 4.8 & - & 2.3 & 1.9 & - \\
\hline $\begin{array}{l}\mathrm{CD} \\
(p=0.05)\end{array}$ & 9.6 & 6.4 & - & 21.5 & 12.3 & - \\
\hline
\end{tabular}
HT- $40 / 24{ }^{\circ} \mathrm{C}$ day/night)

fruit set in all the tested genotypes with overall mean of $18.2 \%$ against $4.8 \%$ fruit set in Royal Wonder. At HT regime, highest fruit setting was observed in Pepsi-17-2 (46.0\%) followed by the genotype S-217621 (36.4\%). Notably no fruit set was observed at HT in genotypes PBC-535 and Faslima. Inability to produce adequate amounts of viable pollen has been associated with decreased fruit set and fewer seed number fruit ${ }^{-1}$ in maize and Capsicum spp. when high temperature coincided with flowering (Schoper et al., 1987 and Reddy and Kakani, 2007). Pollen viability of Royal Wonder (sensitive check) decreased from $100 \%$ at OT to $30 \%$ at HT. Pollen viability of hot pepper genotypes varied from $80-100 \%$ at OT (Table 1). Even at HT all hot pepper genotypes maintained pollen viability equal to or more than $60 \%$. This indicated that impairments in other processes like pollen germination or fertilization but not pollen viability may be responsible for reduced fruit set at high temperature in hot pepper. High temperature not only reduced the fruit setting but also deteriorated fruit quality in terms of reduction in seed number per fruit, fruit length and fruit diameter (Table 2). Seed number fruit ${ }^{-1}$ ranged from 16.8 (Faslima) to 69.7 (MS-12) with average seed number fruit ${ }^{-1}$ of 49.4 at OT regime. However at HT regime, seed number fruit $^{-1}$ ranged from 11.7 (Pepsi-17-2) to 50.0 (Sel Dev) with 
average seed number fruit ${ }^{-1}$ of 25.5. Maximum reduction in seed number fruit ${ }^{-1}$ was observed in PLS-1 (60.8\%) followed by the genotype Sel.11 (54.3\%). Minimum reduction in seed set was observed in Sel-Dev (7.4\%) followed by genotypes DCL-524 (29.3\%) and it was statistically at par with Punjab Surkh (30.1\%). Seed number fruit ${ }^{-1}$ in Royal Wonder was 8.0 and 2.0 at OT and HT, respectively. High seed set during heat stress in tomato has been reported to be an important indicator of heat stress tolerance as the production of viable seed is often reduced under heat stress (Berry and Rafique-Uddin, 1988). The genotype Faslima recorded longest and widest fruits at OT (Table 2). Royal Wonder exhibited 25.5 and $22.4 \%$ reduction

\begin{tabular}{lccccccccc}
\hline \multicolumn{1}{c}{ Table 2: Effect of temperature on fruit quality of different hot pepper genotypes. (OT-34/16 ${ }^{\circ} \mathrm{C}$ day/night, HT-40/24 ${ }^{\circ} \mathrm{C}$ day/night) } \\
\hline \multicolumn{1}{c}{ Genotype } & \multicolumn{7}{c}{ Seed No. fruit ${ }^{-1}$} & \multicolumn{7}{c}{ Fruit length $(\mathrm{cm})$} & \multicolumn{5}{c}{ Fruit width $(\mathrm{mm})$} \\
Sel-11 & OT & HT & HSI & OT & HT & HSI & OT & HT & HSI \\
PLS-1 & 52.5 & 24.0 & 1.10 & 6.35 & 4.5 & 0.97 & 11.10 & 7.29 & 1.10 \\
Sel. Dev & 51.0 & 20.0 & 1.24 & 9.70 & 8.8 & 0.3 & 13.96 & 12.69 & 0.29 \\
DCL-524 & 54.0 & 50.0 & 0.14 & 7.90 & 7.4 & 0.2 & 14.31 & 13.19 & 0.26 \\
Punjab Surkh & 57.3 & 40.5 & 0.59 & 5.60 & 4.9 & 0.4 & 11.95 & 10.72 & 0.32 \\
VR-16 & 57.2 & 40.0 & 0.61 & 4.69 & 4.2 & 0.33 & 11.76 & 10.37 & 0.39 \\
Pepsi-17-2 & 27.7 & 15.5 & 0.90 & 5.72 & 5.11 & 0.37 & 10.45 & 7.71 & 0.84 \\
PBC-535 & 20.7 & 11.7 & 0.88 & 6.60 & 5.7 & 0.47 & 16.83 & 13.65 & 0.61 \\
MS-12 & 69.0 & - & 2.04 & 5.80 & - & 3.33 & 10.43 & - & 3.23 \\
S-217621 & 69.7 & 39.0 & 0.90 & 3.20 & 2.95 & 0.27 & 13.41 & 10.6 & 0.68 \\
Faslima & 67.8 & 40.0 & 0.84 & 7.16 & 7.13 & 0 & 13.11 & 12.99 & 0 \\
Royal Wonder & 16.8 & - & 2.04 & 10.50 & - & 3.33 & 22.19 & - & 3.23 \\
SEm \pm & 8.0 & 2.0 & 1.53 & 4.7 & 3.5 & 0.87 & 49.56 & 38.44 & 0.71 \\
CD $(p=0.05)$ & 7.2 & 3.4 & - & 0.7 & 0.9 & - & 1.2 & 0.8 & - \\
\hline
\end{tabular}

in length and width of fruits, respectively, at HT. The genotype Sel-11 exhibited maximum reduction in fruit size both in terms of length $(29.1 \%)$ and width (34.3\%) of fruits while no significant reduction in fruit size was observed in the genotype S-217621. Maintenance of higher grain number ear ${ }^{-1}$, grain weight main shoot ${ }^{-1}$ and 1000 grain weight are considered important criteria for selection of heat tolerant genotypes in wheat also (Tahir et al., 2006).

Heat susceptibility index (HSI) was used to measure heat stress tolerance of hot pepper germplasm for identifying genotypes exhibiting minimum reduction in fruit set percentage, pollen viability, seed number fruit ${ }^{-1}$, fruit length and fruit diameter due to high temperature. On the basis of HSI for fruit set, only one genotype Pepsi-17-2 was classified as highly heat tolerant $(\mathrm{HSI}<0.5)$. Four genotypes namely DCL-524, VR-16, MS-12 and S-217621 were classified as moderately heat tolerant, showing HSI between 0.5 and 1.0. All other genotypes had HSI $>1.0$ and were classified as heat sensitive. Apparently, five genotypes viz., Pepsi-17-2, DCL-524, VR-16, MS-12 and S-217621 are most promising to initiate hybrid breeding program for the development of heat tolerant cultivars of chilli due to maintenance of better fruit set even under high temperature $(\mathrm{HSI}<1.0)$. For pollen viability, genotypes Pepsi-17-2 and MS-12 were classified as highly heat tolerant having HSI 0 and 0.33 , respectively and other three genotypes (DCL-524, VR-16 and S-217621) were moderately heat tolerant having HSI $>0.5$ to $<1.0$. However, all of these five genotypes were classified as moderately heat tolerant for seed number fruit ${ }^{-1}$ and highly heat tolerant for fruit length. Two genotypes DCL- 524 and S- 217621 were highly heat tolerant for fruit diameter and exhibited HSI values equal to 0.32 and 0 , respectively and other three genotypes (Pepsi-17-2, VR-16 and MS-12) were classified as moderately heat tolerant having HSI $>0.5$ to $<1.0$ (Table 1 and 2). (Pradhan et al., 2012) identified heat tolerant accessions belonging to Aegilops spp. based on HSI for grain yield. On the basis of cumulative temperature response index (CTRI), twelve cultivars of ornamental pepper were classified into heat-sensitive, intermediate and heat-tolerant (Gajanayake et al., 2011). Due to global warming, high temperature is going to be major constraint to commercial production of vegetable peppers in the future emphasizing the urgent need to develop cultivars with higher heat tolerance (Jifon et al., 2004).

\section{Conclusion}

Among the eleven genotypes screened for heat tolerance, only five genotypes namely Pepsi-17-2, DCL- 524, VR-16, 
MS-12 and S-217621 were identified as highly heat tolerant having $\mathrm{HSI}<1.0$ for fruit set and are most promising to initiate hybrid breeding program for the development of heat tolerant cultivars of chilli.

\section{References}

Anonymous, 2011. Package of Practices for Cultivation of Vegetables. Punjab Agricultural University, Ludhiana, India.

Berke, T., Black, L.L., Talekar, N.S., Wang, J.F., Gniffke, P., Green, S.K., Wang, T.C., Morris, R., 2005. Suggested cultural practices for chilli pepper. International CoOperator's Guide.

Berry, S.Z., Rafique-Uddin, M., 1988. Effect of high temperature on fruit set in tomato cultivars and selected germplasm. HortScience 23, 606-608.

Erickson, A.N., Markhart, A.H., 2002. Flower developmental stage and organ sensitivity of bell pepper (Capsicum annuum L.) to elevated temperature. Plant Cell Environment 25, 123-30.

Fischer, R.A., Maurer, R., 1978. Drought resistance in spring wheat cultivars. I. Grain yield responses. Australian Journal of Agricultural Research 29, 897-912.

Gajanayake, B., Trader, B.W., Reddy, K.R., Harkess, R.L., 2011. Screening ornamental pepper cultivars for temperature tolerance using pollen and physiological parameters. HortScience 46, 878-884.

Jifon, J., Crosby, K., Leskovan, D., 2004. Heat stress tolerance in closely related genotypes of Habanero pepper (Capsicum chinensis Jacq). Proceedings of $17^{\text {th }}$ International Pepper Conference, Naples, Florida, USA. 10.

Long, S.P., Ort, D.R., 2010. More than taking the heat: crops and global change. Current Opinion in Plant Biology 13, 241-248.

Pradhan, G.P., Prasad, P.V.V., Fritz, A.K., Kirkham, M.B.,
Gill, B.S., 2012. High temperature tolerance in Aegilops species and its potential transfer to wheat. Crop Science 52, 292-304.

Prasad, P.V.V., Pisipati, S.R., Ristic, Z., Bukovnik, U., Fritz, A.K., 2008. Impact of nighttime temperature on physiology and growth of spring wheat. Crop Science 48, 2372-2380.

Reddy, K.R., Kakani, V.G., 2007. Screening Capsicum species of different origins for high temperature tolerance by in vitro pollen germination and pollen tube length. Scientia Horticulturae 112, 132-135.

Ristic, Z., Bukovnik, U., Prasad, P.V.V., 2007. Correlation between heat stabilization of thylakoid membranes and loss of chlorophyll in winter wheat under heat stress. Crop Science 47, 2067-2073.

Schoper, J.B., Lambert, R.J., Vasilas, B.L., 1987. Pollen viability, pollen shedding and combining ability for tassel heat tolerance in maize. Crop Science 27, 27-31.

Singh, S., Bansal, M.L., Singh, T.P., Kumar, R., 1991. Statistical Methods for Research Workers. Kalyani Publishers, New Delhi, India. pp 287-301.

Tahir, I.S.A., Nakata, N., Ali, A.M., Mustafa, H.M., Saad, A.S.I., Takata, K., Ishikawa, N., Abdaka, O.S., 2006. Genotypic and temperature effects on wheat grain yield and quality in a hot irrigated environment. Plant Breeding 125, 323-330.

Usman, M.G., Rafii, M.Y., Ismail, M.R., Malek, M.A., Latif, M.A., 2014. Heritability and genetic advance among chili pepper genotypes for heat tolerance and morphophysiological characteristics. The Scientific World Journal Article ID: 308042, 14.

Wahid, A., Gelani, S., Ashraf, M., Foolad, M.R., 2007. Heat tolerance in plants: An overview. Environmental and Experimental Botany 61, 199-223. 